SCJR 16, no. 1 (2021): 1-4

\title{
Amy-Jill Levine and Marc Zvi Brettler The Bible With and Without Jesus: How Jews and Christians Read the Same Stories Differently
}

(New York: HarperOne, 2020), 512 pages

\author{
MICHAEL TRAINOR \\ michael.trainor@acu.edu.au \\ Australian Catholic University, Thebarton, SA 5031
}

As a university Bible scholar and Christian educator, I was confident in the breadth of my knowledge of Scripture. However, after reading this book I realized there is so much I do not know! Because of their remarkable familiarity with the Bible and its interpretation, Levine and Brettler offer valuable insights to Christian and Jewish readers, whether lay or scholarly. These insights are consistently respectful of both traditions, expansive, and conducive to dialogue.

There are three questions that shape the authors' approach in each chapter: "What did the [biblical] text mean in its original context in ancient Israel? How do the New Testament authors interpret that text? And how do post-biblical Jews from the time of Jesus (e.g., the Dead Sea Scrolls, the first-century historian Josephus, and the first-century philosopher Philo) through the rabbinic and medieval Jewish tradition and later Christian traditions understand these texts?" (xi). The book's title also illustrates this approach. The authors treat three subjects equally: the Bible, the Bible with Jesus, and the Bible without Jesus (x).

The authors invite their readers to reflect on biblical texts, starting with their appearance in the Tanakh and then later on with their appearance in the New Testament and in subsequent interpretations. Their agenda is not to reconcile different interpretations of biblical texts but to honor the differences (15). Levine and Brettler adopt multiple lenses to perform an "act of recovery" (xii), as they call it, making readers more aware of these texts. In light of their backgrounds and teaching experiences, I suspect this reflects the frustration they feel over widespread ignorance even from some Christian biblical interpreters and educators about Judaism and Jewish interpretation. Their desire is for Jews and Christians to "understand each other's positions and beliefs and at the minimum respectfully agree to disagree" (4). 
While space limitations do not allow me to offer a comprehensive overview of the book, in the following I offer brief precis of each of the chapters. Then I focus on one theme, virginity, that the authors explore in order to illustrate their approach and the contributions that it can make to Christian and Jewish understanding.

Chapter 1 offers a summary of different views of what constitutes "the Bible" (and its interpretation), highlighting its prominent role shaping religious practice for Jews and foreshadowing the New Testament for Christians.

Chapter 2 presents a study of prophecy, how it was understood, and what they call its "problem and promise" (41). They discuss how prophecy was viewed in ancient Israel until the Second Temple Period (up to ca. 515 BCE) and how this provided the context for later NT writers, who were themselves interpreters of prophetic texts (sometimes as proof texts) and used them to understand Jesus. Sympathetic recognition of the different ways these texts have been read, they say, is good for civil society and religious commitment (60).

Chapters 3-12, the book's main chapters, each focus on a particular text or theme, usually from the New Testament, and then move backward chronologically to the Tanakh in order to recover the original context and meaning. The authors illustrate how the incorporation or borrowing of these texts or themes in the New Testament are used to support particular christological viewpoints divorced from their original biblical settings or anticipatory hints of the life, death, and resurrection of Jesus.

Chapter 3 explores the theme of creation. The authors begin with the prologue from John's Gospel (1:1-5) and then reflect on the story of Creation from Genesis and from later Jewish interpretations.

Chapter 4 treats biblical themes associated with the Genesis story of Adam and Eve including responsibility for the transgression, the forbidden fruit, and (original) sin. Even the snake gets a mention!

Chapter 5 takes up the problem of supersessionism. Levine and Brettler identify this in Hebrews and explicate the implications of identifying Jesus as the "eternal high priest after the order of Melchizedek" (7:17).

Chapter 6 focuses on the main injunctions of the Sermon on the Mount in Matthew 5-7. They argue that Jesus' teachings are extensions of commands in the Torah rather than antitheses.

Chapter 7 presents interpretations of biblical themes of sacrifice, blood, atonement, and covenant in order to help Christians to freshly understand Jesus' Last Supper injunction to drink his blood.

Chapter 8 explores biblical ideas of virginity and their application to Mary in Matthew's Gospel. The authors illustrate how Matthew draws on Isaiah and how his prophetic "predictions" became a source of polemic. I shall briefly return to this theme below in order to illustrate the contributions which The Bible With and Without Jesus can make especially to Christian understanding of Mary's virginity.

Chapter 9 discusses Isaiah's Suffering Servant and how he became a template for Jesus' followers in their understanding of his suffering and death. 
Chapter 10 considers the figure of Jonah and how he is understood by Jews and later by Christians.

Chapter 11 invites deeper consideration of the so-called "cry of dereliction," the words that Mark and Matthew place on the lips of the dying Jesus: "My God, My God, why have you forsaken me?" They show how the evangelists' use of this quotation of Psalm 22 illustrates how they appropriate and reinterpret the psalm as a prediction of Jesus' fate.

Chapter 12 concentrates on a prominent but vexing title applied to Jesus: "Son of Man." The chapter uncovers the rich Jewish tradition behind this title as found in Genesis, Numbers, Psalms, and Job.

Before I reflect on the book's final chapter and its insights for ongoing JewishChristian dialogue and biblical interpretation, let me summarize the contribution which the authors make in chapter 8 to Christian understanding of Mary's virginity. The key text is from Matthew. The evangelist applies Isaiah 7:14 to Mary's pregnancy: "'Look, the virgin shall conceive and bear a son, and they shall name him Emmanuel,' which means 'God is with us"' (1:20-23). Levine and Brettler focus on the Hebrew 'almah in Isaiah, which means "a young woman of marriageable age." This was translated in the Septuagint as parthenos, which means "a virgin in the sense of a sexually inexperienced person" (271). The Hebrew version was lost to later Christian interpreters, who relied on the Greek text and its application to Mary's pregnancy. This transposition of 'almah to parthenos unfortunately led to Jewish-Christian polemics, as in Justin's Dialogue with Trypho. Matthew's use of parthenos does not rule out the possibility that Mary, who is not yet pregnant (the future tense "shall conceive" suggests this), is still a virgin. At the time of the writing of Matthew, Jews would have been aware of stories of divine beings' having sexual relations with humans. Mary's virginity thus would not necessarily have been heard by Jews, including by Jewish Jesus-followers in Matthew's community, as unprecedented. For Christians today, this discussion about claims of Mary's virginity in their ancient Jewish context can open other ways of thinking about the mother of Jesus that move away from a gynecological emphasis that has historically dominated Christian interpretation.

In the book's last chapter, Levine and Brettler suggest several insights that emerge from their work. They acknowledge the importance of reclaiming the original context and setting of biblical texts, the value of working with the original languages, the ethical implications that come from diverse and multiple interpretations, and the rich insights available to Jews and Christians by learning the meanings of the texts from the other's tradition. "We have accentuated," they write, "how Christians might increase their appreciation of the 'Old Testament' texts cited in the New Testament, as well as how those texts have ongoing meaning in the Jewish tradition.... We also want to encourage our Jewish readers to see how the various quotations from their own scriptures are used in the New Testament, for several of the New Testament writers, especially Paul, are reading and writing from within their own Jewish tradition" (426). 
The Bible With and Without Jesus deserves a wide readership. It is a scholarly gift that will enhance Jewish-Christian dialogue and biblical interpretation by Jews and Christians. 